\title{
Application of Tactical Approach to Developing Students' Enjoyment and Skills in Playing Football
}

\author{
Sucipto*, Yunyun Yudiana, Burhan Hambali, Lilis Komariyah, Agus Gumilar \\ Physical Education Health and Recreation Study Program, Universitas Pendidikan Indonesia, Bandung, Indonesia
}

Received April 23, 2021; Revised July 14, 2021; Accepted July 22, 2021

\section{Cite This Paper in the following Citation Styles}

(a): [1] Sucipto, Yunyun Yudiana, Burhan Hambali, Lilis Komariyah, Agus Gumilar, "Application of Tactical Approach to Developing Students' Enjoyment and Skills in Playing Football," International Journal of Human Movement and Sports Sciences, Vol. 9, No. 4A, pp. 100 - 105, 2021. DOI: 10.13189/saj.2021.091317.

(b): Sucipto, Yunyun Yudiana, Burhan Hambali, Lilis Komariyah, Agus Gumilar (2021). Application of Tactical Approach to Developing Students' Enjoyment and Skills in Playing Football. International Journal of Human Movement and Sports Sciences, 9(4A), 100 - 105. DOI: 10.13189/saj.2021.091317.

Copyright $\odot 2021$ by authors, all rights reserved. Authors agree that this article remains permanently open access under the terms of the Creative Commons Attribution License 4.0 International License

\begin{abstract}
This study aimed to examine the effect of tactical approach on students' enjoyment and skills in playing football. The study used an experimental method with a pre-test post-test control group design. A total of 40 students aged 14-15 years were involved in the study at one of junior high schools in West Bandung Regency, Indonesia. Data were collected using the Pleasure Scale and Game Performance Assessment Instruments (GPAI) which were aimed to measure the level of enjoyment and skills of the students in playing football. The measurement data were analysed using the one-way MANOVA technique. The results of the analysis showed that the $\mathrm{F}$ value $(\mathrm{df}=37)$ was $47.57, \mathrm{p}$ value $=0.00$. These results indicate that the learning approaches given to students, both tactical and technical approaches, have a significant effect on the enjoyment and skills of playing football in a multivariate manner. While the analysis of the mean comparison between the two groups obtained $\mathrm{p}$ value $=$ 0.00 . This proves that the tactical approach has a higher and significant effect on the development of enjoyment and football playing skills. The results of the analysis also conclude that the application of tactical approach has a significant effect on the development of students' enjoyment and playing skills.
\end{abstract}

Keywords Enjoyment, Football Playing Skills, Tactical Approach

\section{Introduction}

One of the problems that pose a challenge in the Physical Education learning process is the low professionalism of Physical Education teachers, so that Physical Education teachers seem to not have a professional skill [1]. The findings are found from the facts in the field, where there are still a number of students who do not want to take Physical Education lessons because it seems boring and uninteresting [2]. This is not relevant to the concept that should occur in Physical Education learning as expressed by Prochaska, Sallis, Slymen, \& McKenzie, who state that one of the missions of Physical Education is the promotion of participation and enjoyment in Physical Activities [3].

Teaching skill is one of the most important indicators in the process of achieving learning outcomes, so that the main role in teaching is to prompt reliable learners or the so-called powerful learners [4]. Therefore, a teacher plays a strategic role in the learning process, where the teacher self-ability in teaching has shown a positive relationship with various educational outcomes, including student learning outcomes [5].

The teacher understanding to carry out the process of change in teaching, especially in the Physical Education teaching, is important because Physical Education teachers have different characteristics from general education teachers in the learning process [6]. There are five basic program elements in the pedagogical change, including 1) curriculum, 2) teaching strategies, 3) 
classroom management techniques, 4) assessment, and 5) learning environment [7]. The five elements of pedagogical change should be a teacher's focus of attention because changes in pedagogical elements are expected to be indicators of achieving learning objectives. One element of the pedagogical change that often becomes an issue in the learning process is the learning approach.

The success of learning outcomes from the cognitive, affective, and psychomotor aspects is influenced by the learning approach used by adjusting the material to be taught. Therefore, the learning approach is a key factor affecting the quality of learning outcomes [8]. At the practical level, there are two approaches that are often used in the Physical Education learning process, including the technical approach and the tactical approach [9].

Tactical approach is a teaching approach that emphasizes the student understanding of the nature and goals of the sport being taught, while encouraging children to master skills and apply them directly in game situations [9]. The main objective of the tactical approach in game learning is to improve the student understanding of the game concept, especially in relation to the tactical aspect of the game, so that it is expected to improve student performances $[9,10]$.

In Physical Education learning, the application of the tactical approach aims to motivate students and foster student interest so that they are more active in participating in learning and can perform various basic techniques of a game through playing activities [11]. Therefore, in a teaching perspective, the tactical approach has two main assumptions: 1) to increase student interest and greater excitement and 2) to increase tactical knowledge and playing proficiency for all students [12].

At the practical level, there are four components of the tactical approach cycle, namely 1) Initial game, 2) Discussion in the context of a question and answer guided by the teacher, 3) Implementation of learning practices that are relevant to the results of the discussion and 4) Implementation of the game in the context of the actual game [12]. Therefore, the tactical approach emphasizes the game-drill-game process or can be interpreted as a game approach [13].

The results of research conducted by Gubacs-Collins explain that the tactical approach increased students tactical knowledge and interest and excitement for teachers and students. The strategy for achieving students learning competence, one of the main factors, is by using the right learning approach, including games learning, such as football [12]. In addition, Osman conducted research on the impact of the application of the TGFU model on tactical awareness and decision making in playing football. The design used the pre-test and post-test research involving 20 students who were randomly selected to receive a learning program using the application of TGFU in football for two months. The results of the study prove that the use of Teaching Games for Understanding (TGFU) in learning has an impact on increasing students tactical awareness and decision making [14].

Based on the studies and global issues that have been described in the previous discussion, learning approach is one of the indicators that has an impact on the success of learning outcomes. It is evidenced by several previous research results which prove that learning approach has an effect on Physical Education learning. Therefore, the researchers tried to apply a tactical approach in Physical Education, especially in the football learning process. This was based on the problems found in the field as a research gap, where there were still a number of students who did not want to take Physical Education lessons because it seemed boring and uninteresting. While conceptually, one of the missions of Physical Education is to encourage participation in physical activities that are expected to bring enjoyment [3]. Therefore, this study examined the effect of tactical approach on the enjoyment and learning outcome developments in playing football in the context of Physical Education learning in Indonesia.

\section{Methods}

\section{Design}

The research design used in this study was a true experimental design [15]. The research involved two groups, namely the experimental group with tactical approach intervention and the control group with technical approach intervention. The basic assumption of using the experimental method in this study was to test the application of the tactical approach in the development of enjoyment and skills in playing football.

\section{Participants}

A total of 40 junior high school students in West Bandung, West Java, Indonesia, were involved in this study as participants. Sampling used two sampling techniques, namely random selection and random assignment [15]. The participants were divided into two groups. Twenty students were included in the tactical approach group, while the other 20 students were included in the technical approach group.

\section{Measurement}

The variables measured in this study were the enjoyment and skills in playing football. Therefore, there were two instruments used in this study, including the enjoyment scale instrument adapted from Kendzierski and DeCarlo called the Physical Activity Enjoyment Scale (PACES), which consists of 18 items. Estimated value of 
content validity (Lawshe's CVR) obtained a ratio value between 0.71 to 1.00 . This value exceeded the minimum limit value $(0.50)$ as the acceptable ratio value limit. Therefore, the results of content validity analysis show that the enjoyment instrument in sports is proven valid to measure the level of student enjoyment in Physical Education learning [16]. The instrument to measure the playing skills was the Game Performance Assessment Instrument (GPAI) $[9,28]$, which was used to measure the results of student performance in performing football skills [17]. Aspects observed in GPAI include behaviour that reflects the player ability to solve tactical problems in football by making decisions, making movements based on the demands of the game situation, and applying the type of skill they choose.

\section{Data Analysis}

The measurement results were analysed using the one way MANOVA technique to see the effect of the learning approach in developing the students enjoyment and skills in playing football in a multivariate and univariate manner.

\section{Results}

\section{Descriptive Statistics}

In providing an overview of the data obtained from the measurement results, the first analysis used a descriptive statistical analysis. The results of the analysis are presented in Table 1.

Table 1. Descriptive Statistic Results of Pretest and Posttest Difference Measurement

\begin{tabular}{|c|c|c|c|c|}
\hline Variable & Approach & Mean & $\begin{array}{c}\text { Std. } \\
\text { Deviation }\end{array}$ & N \\
\hline \multirow{3}{*}{ Enjoyment } & Tactical & 5.0 & 1.5 & 20 \\
\cline { 2 - 5 } & Technical & 2.5 & 1.6 & 20 \\
\cline { 2 - 5 } & Total & 3.8 & 2.0 & 40 \\
\hline \multirow{3}{*}{$\begin{array}{c}\text { Football } \\
\text { Playing Skills }\end{array}$} & Tactical & 6.9 & 1.4 & 20 \\
\cline { 2 - 5 } & Technical & 3.2 & 1.3 & 20 \\
\cline { 2 - 5 } & Total & 5.0 & 2.3 & 40 \\
\hline
\end{tabular}

Based on the statistical description presented in Table 1, in the tactical group, the mean and standard deviation of the difference between the pretest and posttest measurements for the enjoyment variable was $\mathrm{M}=5.0$; $\mathrm{SD}=1.5$. The skill variable obtained a value $\mathrm{M}=6,9 ; \mathrm{SD}$ $=1,4$. Whereas, in the technical group, the mean and standard deviation for the enjoyment variable obtained $\mathrm{M}$ $=2.5 ; \mathrm{SD}=1.6$. The skill variable obtained $\mathrm{M}=3.2 ; \mathrm{SD}=$ 1.3 .

\section{MANOVA Analysis}

Manova analysis was used to see the effect of the learning approach on the development of enjoyment and skills in playing football. The analysis results are presented in Table 2.

Table 2. Multivariate Test

\begin{tabular}{|c|c|c|c|c|c|}
\hline Effect Approach & Value & F & $\begin{array}{c}\text { Error } \\
\text { df }\end{array}$ & Sig. & PES \\
\hline Pillai's Trace & 0.72 & 47.57 & 37.0 & 0.00 & 0.72 \\
\hline Wilks' Lambda & $\mathbf{0 . 2 8}$ & $\mathbf{4 7 . 5 7}$ & $\mathbf{3 7 . 0}$ & $\mathbf{0 . 0 0}$ & $\mathbf{0 . 7 2}$ \\
\hline $\begin{array}{c}\text { Hotelling's } \\
\text { Trace }\end{array}$ & 2.57 & 47.57 & 37.0 & 0.00 & 0.72 \\
\hline $\begin{array}{c}\text { Roy's Largest } \\
\text { Root }\end{array}$ & 2.57 & 47.57 & 37.0 & 0.00 & 0.72 \\
\hline
\end{tabular}

Based on the results of the wilks lambda test analysis on the multivariate test table, it was found that the $\mathrm{F}$ value ( $\mathrm{df}=37$ ) was 47.57 and significant at $\mathrm{p}$ value 0.00 . This shows that the learning approaches given to students, both tactical and technical, had an impact on the development of enjoyment and football skill learning outcomes with a contribution of $72 \%$. This can be seen from the amount of Partial Eta Squared (PES) of 0.72.

Table 3. Test of Between-Subject Effects

\begin{tabular}{|c|c|c|c|c|c|}
\hline $\begin{array}{c}\text { Dependent } \\
\text { Variable }\end{array}$ & df & $\begin{array}{c}\text { Mean } \\
\text { Square }\end{array}$ & F & Sig. & PES \\
\hline Enjoyment & 1 & 62.5 & 26.1 & 0.0 & 0.4 \\
\hline $\begin{array}{c}\text { Football Playing } \\
\text { Skills }\end{array}$ & 1 & 141.0 & 75.3 & 0.0 & 0.7 \\
\hline
\end{tabular}

The results of the analysis in Table 3, Tests of Between-Subjects Effects, show the effect of the approaches on enjoyment development with an F of 26.1 and a significant value of 0.00 . It proves that the tactical and technical approach interventions had an effect on enjoyment development, with a PES value of 0.4 , which means that the contribution of tactical and technical approaches on enjoyment development was $40 \%$.

Meanwhile, the football skill variable obtained an $\mathrm{F}$ value of 75.3 and significant at $p$ value 0.00 . This proves that the tactical and technical approach interventions had an effect on the development of football playing skill learning outcomes, with a PES value of 0.7. This means that the contribution of tactical and technical approaches to the development of football skill learning outcomes was $70 \%$.

Table 4. Pairwise Comparisons

\begin{tabular}{|c|c|c|c|c|c|c|}
\hline $\begin{array}{c}\text { Dependent } \\
\text { Variable }\end{array}$ & \multicolumn{3}{|c|}{$\begin{array}{l}\text { Comparisons } \\
\text { Approach }\end{array}$} & $\begin{array}{c}\text { Mean } \\
\text { Difference } \\
(\text { I-J) }\end{array}$ & $\begin{array}{l}\text { Std. } \\
\text { Error }\end{array}$ & Sig. ${ }^{b}$ \\
\hline Enjoyment & $\begin{array}{c}\text { Tactical } \\
M=5,0\end{array}$ & & $\begin{array}{c}\text { Technical } \\
M=2,5\end{array}$ & 2.5 & 0.49 & 0.00 \\
\hline $\begin{array}{l}\text { Football } \\
\text { Playing } \\
\text { Skills }\end{array}$ & $\begin{array}{l}\text { Tactical } \\
\mathrm{M}=6,9\end{array}$ & & $\begin{array}{c}\text { Technical } \\
M=3,2\end{array}$ & 3.8 & 0.43 & 0.00 \\
\hline
\end{tabular}

Based on the results of the analysis presented in Table 4, Pairwise Comparisons, the p-value comparison between tactical approach and technical approach on the enjoyment 
variable is 0.00 . This proves that there was a significant difference in influence between tactical and technical approaches. Tactical approach $(M=5.0)$ is proven to have a higher impact than the technical approach $(\mathrm{M}=2.5)$ on enjoyment development. While the Football Playing Skill variable obtained a $p$ value of 0.00 , which proves that there was a significant difference in influence between the tactical and technical approaches. The tactical approach $(\mathrm{M}=6,9)$ is proven to have a higher impact than the technical approach $(\mathrm{M}=3,2)$ on the development of Football Playing Skills.

Based on the results of the analysis, it is proven that the two approaches used as interventions had a significant impact on Enjoyment and Football Playing Skills. In general, the tactical approach was shown to have a higher impact than the technical approach.

\section{Discussion}

This study aimed to examine the effect of a tactical approach on the development of enjoyment and skills in playing football. Based on the results of the analysis, it is proven that the two approaches used as interventions have a significant impact on Enjoyment and Football Playing Skills. In general, the tactical approach had been shown to have a higher impact than the technical approach.

The results of the multivariate analysis show that the learning approach given to students had an impact on the development of enjoyment and learning outcomes of football skills with a contribution of $72 \%$, while the results of the Pairwise Comparisons analysis prove that there was a significant difference in influence between tactical and technical approaches. Tactical approaches are proven to provide a higher impact than the technical approach in enjoyment and Football Playing Skill developments.

Based on the results of this analysis, this study can contribute and support the study of theories and concepts regarding the learning approach, as we know that the success of Physical Education learning outcomes is influenced by the learning approach used. Learning approach is one of the key factors that can affect the quality of learning outcomes [8]. Therefore, at the practical level, there are two approaches that are often used in the Physical Education learning process, namely the technical approach and the tactical approach. The difference between the two approaches lies in the learning stages [9]. One of the strategies for achieving students competences in learning is to use an appropriate learning approach [12].

It is proven that the tactical approach can have a higher impact than the technical approach, basically because the tactical approach has two main assumptions, namely 1) it is carried out to increase a greater interest and excitement for students and 2) increase tactical knowledge and playing proficiency for all students [12]. Whereas, the technical approach tends to a traditional approach in teaching games, which, in reality, does not stimulate the student interest in learning; it does not even improve their ability to play [9].

There are four cycle components in the tactical approach, namely: 1) Early game, 2) Discussion of the question and answer session guided by the teacher, 3) Learning practices that are relevant to the results of the discussion, and 4) Implementation of the actual game [12]. The four components are presented further in Figure 1.

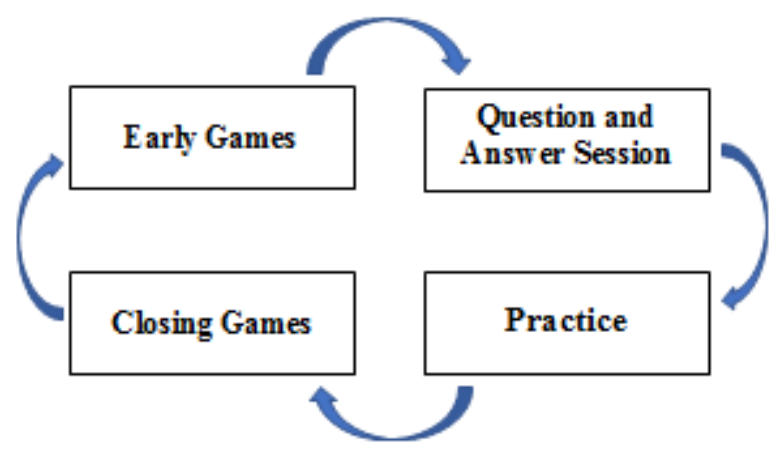

Figure 1. Components of Tactical Learning Sequence [12]

The results of this study support some of the results of previous research conducted by Gubacs-Collins which explain that tactical approach increases the student tactical knowledge and increases interest and the excitement of teachers and students [12]. It increases metacognitive behaviours in Physical Education classes [18]. Learning games through a tactical approach will get joy, excitement, and motivation [19]. In addition, the results of this study support the concept developed that one of the missions of Physical Education is the promotion of participation in fun physical activities [3].

The result of previous research that supports this study is a research conducted by Osman recommending the objectives of the Teaching Games for Understanding (TGFU) as a useful approach for all teachers in improving technical skills and transferring training into competitive situations $[20,27]$. Then, Nathan conducted research by comparing the Teaching Games for Understanding (TGFU) and Skill Drill Technic (SDT) models to Junior Hockey players. The results of this study proved that the TGFU-based approach has a significant impact on the measured variables [21]. Robertson conducted research regarding the relationship between TGFU and pleasure, self-confidence, and the desire to participate in physical activities in Secondary Schools [22]. However, the results of the research carried out are not commensurate with the results of other studies. The results of the application of the TGFU model by Robertson proved to have no significant effect, even as if they were static from the results of the pre-test and post-test. Then, Hodges, Wicke, and Flores examined tactical game models and their effects on the student physical activity and gameplay 
performance in Physical Education [23], as well as Dorak, Yildiz, A. Canpolat, Yasin \& Vurgun who examined the comparison of game approaches, tactical, and direct teaching models in Handball teaching by measuring cognitive, psychomotor, and game performance aspects [24].

The results of this study conclude that the tactical approach has a significant impact on enjoyment or excitement in doing game learning activities, especially for first-time school students [29,30], while the technical approach did not stimulate the student interest in learning [31]. It does not even improve their ability to play [32]. Based on this study, describing the interest of adolescents in sports, both for male and female, football sports can be used as a medium for developing educational values. This is because football is popular among children, parents, male, and female [33,34].

The age of students in Junior High School ranges from 13 to 15 years. At that age, they are classified as adolescence, where adolescence is a period of change from childhood to adulthood. For this reason, Physical Education teachers take a good opportunity to channel their interests and talents to physical activities that contain educational values in intra-curricular, co-curricular, and extra-curricular activities in their schools. This is in line with the concept of Hurlock, "sports will provide opportunities for adolescents to try to elevate themselves as individuals who have proud self-esteem" [25]. In addition, Rocco and Paulini, as big philosophers, state that "sports for adolescents are activities that can provide positive experiences for their lives. Because through sports, teenagers are directed to learn sportsmanship and to be leaders" [26].

\section{Conclusion}

Based on the results of the analysis and discussion of the study, it concludes that learning approach has a significant impact on learning outcomes in Physical Education. The application of a tactical approach has been proven to have an impact on the development of enjoyment and football playing skills.

\section{Acknowledgments}

The authors would like to thank all those who have helped the authors in this research process, especially the Physical Education teachers, the Faculty of Sport and Health Education, and the Institute of Research and Community Service, Universitas Pendidikan Indonesia, who have funded this study.

\section{REFERENCES}

[1] Sucipto, et al. The Implementation of Tactical Approach in Developing Football Games Performance and Understanding of Junior High School Students. Jurnal Pendidikan Jasmani dan Olahraga. 2020. 5(1):70-5.

[2] Sucipto S. The Implementation of Tactical Approach on Students' Enjoyment in Playing Football in Junior High School. Jurnal Pendidikan Jasmani dan Olahraga. 2019. 4(1):14-20.

[3] Prochaska JJ, Sallis JF, Slymen DJ, McKenzie TL. A longitudinal study of children's enjoyment of physical education. Pediatric Exercise Science. 2003 May 1;15(2):170-8.

[4] Joyce B, Weil M, Calhoun E. Models of Teaching, Model-Model Pengajaran, terj. Achmad Fawaid dan Ateilla Mirza. Yogyakarta: Pustaka Pelajar. 2011.

[5] Goddard RD, Hoy WK, Hoy AW. Collective teacher efficacy: Its meaning, measure, and impact on student achievement. American educational research journal. 2000;37(2):479-507.

[6] Whipp PR, Tan G, Yeo PT. Experienced physical education teachers reaching their "use-by date" powerless and disrespected. Research quarterly for exercise and sport. 2007 Dec 1;78(5):487-99.

[7] Kern BD, Graber KC. Physical education teacher change: Initial validation of the teacher change questionnaire-physical education. Measurement in Physical Education and Exercise Science. 2017 Jul 3;21(3):161-73. https://doi.org/10.1080/1091367X.2017.1319371

[8] Davidson RA. Relationship of study approach and exam performance. Journal of Accounting Education. 2002 Dec 1;20(1):29-44. DOI: 10.1016/S0748-5751(01)00025-2

[9] Griffin LL, Mitchell SA, Oslin JL. Teaching sports concepts and skills: A tactical games approach. Human Kinetics Publishers (UK) Ltd; 1997.

[10] Mitchell S, Mitchell SA, Oslin J, Griffin LL. Teaching sport concepts and skills: A tactical games approach. Human Kinetics Publishers; 2020.

[11] Meti, Sultamengtyas. Gatot, D. Dribbling dan Controling Dalam Sepak Bola (Studi Pada Siswa Kelas VIII SMP Negeri 26 Surabaya), 6(2016), 60-64.

[12] Gubacs-Collins K. Implementing a tactical approach through action research. Physical Education and Sport Pedagogy. 2007 Jun 1; 12(2): 105-26. https://doi.org/10.1080/17408980701281987

[13] Ridwan M, Darmawan G, Indiarsa N. Upaya Meningkatkan Penguasaan Keterampilan Passing Pada Permainan Sepakbola Melalui Pendekatan Taktis. BRAVO'S (Jurnal Prodi Pendidikan Jasmani \& Kesehatan). 2017 Aug 28;5(1).

[14] Osman AS. Effects of teaching games for understanding on tactical awareness and decision making in soccer for college students. Ovidius University Annals, Series Physical Education and Sport/Science, Movement and Health. 2017 Jun 15;17(2):170-7. 
[15] Fraenkel JR, Wallen NE, Hyun HH. How to design and evaluate research in education. New York: McGraw-Hill; 2012.

[16] Sucipto S, Tarigan B, Ma'mun A, Yudiana Y. Content Validity of the Enjoyment Instrument in Physical Education Learning: A Field Study. In3rd International Conference on Sport Science, Health, and Physical Education (ICSSHPE 2018) 2019 Sep. Atlantis Press.

[17] Harvey S, Cushion CJ, Wegis HM, Massa-Gonzalez AN. Teaching games for understanding in American high-school soccer: A quantitative data analysis using the game performance assessment instrument. Physical Education and Sport Pedagogy. 2010 Jan 1;15(1):29-54.

[18] Chatzipanteli A, Digelidis N, Karatzoglidis C, Dean R. A tactical-game approach and enhancement of metacognitive behaviour in elementary school students. Physical Education and Sport Pedagogy. 2016 Mar 3;21(2):169-84.

[19] Mitchell SA, Oslin JL, Griffin LL. Teaching sport skills: A tactical games approach. Champaign, IL: Human Kinetics, 2006.

[20] Osman AS. Effects of teaching games for understanding on tactical awareness and decision making in soccer for college students. Ovidius University Annals, Series Physical Education and Sport/Science, Movement and Health. 2017 Jun 15;17(2):170-7.

[21] Nathan S. The effect of Teaching Games of Understanding as a coaching instruction had on adjust, cover and heart rate among Malaysian and Indian junior hockey players. Sports. 2017 Jun;5(2):44.

[22] Robertson S. Investigating the Relationship between Teaching Games for Understanding and High School Physical Education Students' Enjoyment, Self-Efficacy, and Intentions to Enroll. 2016.

[23] Hodges M, Wicke J, Flores-Marti I. Tactical games model and its effects on student physical activity and gameplay performance in secondary physical education. Physical Educator. 2018;75(1):99-115.

[24] Dorak F, Yildiz L, Canpolat AM, Yüzbasioglu Y, Vurgun N.
A Comparison of the Tactical Game Approach and the Direct Teaching Models in the Teaching of Handball: Cognitive-Psychomotor Field and Game Performance. World Journal of Education. 2018;8(3):76-85.

[25] Hurlock EB. Adolescent development..1994

[26] Rocco, D.. Adolescence: Change and Continuity Sports., 2002

[27] Harvey S, Gil-Arias A, Claver F. Effects of Teaching Games for Understanding on tactical knowledge development in middle school physical education. Journal of Physical Education and Sport. 2020;20(3):1369-79.

[28] Arias-Estero J, Castejón F. Using instruments for tactical assessment in physical education and extra-curricular sports. European Physical Education Review. 2014 Nov;20(4):525-35.

[29] Gubacs-Collins K, Olsen EB. Implementing a tactical games approach with sport education: A chronicle. Journal of Physical Education, Recreation \& Dance. 2010 Mar 1;81(3):36-42.

[30] Layne TE, Hastie PA. Analysis of teaching physical education to second-grade students using sport education. Education 3-13. 2016 Mar 3;44(2):226-40

[31] Holmes MR, Tracy EM, Painter LL, Oestreich T, Park H. Moving from flipcharts to the flipped classroom: Using technology driven teaching methods to promote active learning in foundation and advanced masters social work courses. Clinical social work journal. 2015 Jun $1 ; 43(2): 215-24$

[32] Camiré M, Trudel P, Forneris T. High school athletes' perspectives on support, communication, negotiation and life skill development. Qualitative research in sport and exercise. 2009 Mar 1;1(1):72-88.

[33] Ratna A. 'Who wants to make aloo gobi when you can bend it like Beckham?' British Asian females and their racialised experiences of gender and identity in women's football. Soccer \& Society. 2011 May 1;12(3):382-401.

[34] Brackenridge $\mathrm{CH}$. Children's rights in football: Welfare and work. 